\title{
Identification of European and Japanese Larch and Their Interspecific Hybrid with Morphological Markers: Application to Young Seedlings
}

\author{
By L. E. PÂques ${ }^{1) * *)}$, G. Philippe ${ }^{2)}$ and D. PraT ${ }^{3)}$
}

(Received 30 $0^{\text {th }}$ November 2005)

\begin{abstract}
Open-pollinated hybridisation seed orchards of European and Japanese larches produce mixed progenies combining a highly variable proportion of hybrids along with pure parental species. For several reasons, it is desirable to identify and to sort out hybrids from pure species at the seedling stage. Taxa identification of 1-2 yr-old seedlings was attempted using non-destructive assessment of several traits, including morphology, phenology, growth and architecture parameters. Two sets of progenies originating from 10 open-pollinated hybridisation seed orchards were used, relying in a first step on taxa identification of individual seedlings with diagnostic molecular markers. Based on 21 traits assessed, some clear trends in pure species and hybrid features were apparent but due to the large and overlapping ranges of taxa characteristics, no single parameter allowed unambiguous identification of taxa. Combination of traits through linear discriminant analysis made possible correct classification of $90.2 \%$ to $98.6 \%$ of individuals depending on the orchard although there were a few problematic orchards. Two traits appeared particularly pertinent for discriminating young plants taxa, namely $1^{\text {st }}$-yr leaf retention (marcescence) and the bark colour of $2^{\text {nd }}$-year shoot increments. Results were corroborated using progenies from several orchards and over two experimental periods.
\end{abstract}

Key words: Larix, taxonomy, hybrid, seedling, morphology, phenology, growth, linear discriminant analysis, seed orchard.

\section{Introduction}

Among species of the Larix genus, two are of particular importance for Western European forestry, namely European larch (Larix decidua Mill., coded 'EL') and Japanese larch (L. kaempferi (Lamb.) Carr, coded 'JL'). Their interspecific hybrid (coded 'HL') proved also to be of high value for lowlands reforestation and since its first observation in Scotland at the beginning of the $20^{\text {th }}$ century (HENRY and FLOOD, 1919), hybrid larch has been the object of intensive breeding work across Europe.

From the late 1940s on, over 30 hybridisation seed orchards have been established across Europe to massproduce improved hybrid larch (DESTEucQ, 2003). Their genetic composition, design and combination types are various but nearly all of them rely on open-pollination.

1) INRA, Centre d'Orléans, Unité d'Amélioration, Génétique et Physiologie des Arbres forestiers, F-45160 Ardon (France).

2) Cemagref, Unité 'Ecosystèmes forestiers', F-45290 Nogent-surVernisson (France).

3) Université Claude Bernard - Lyon 1, Génome et Evolution des Plantes Supérieures, F-69622 Villeurbanne (France).

*) Luc E. PÂques, Tel. +33 2384178 21, Fax: +33 2384178 79, e-mail: paques@orleans.inra.fr
Because of incomplete overlapping of the flowering periods of European and Japanese larch and often unfavourable climatic conditions during anthesis and pollination, seed production is erratic, both quantitatively and qualitatively. Besides a low percentage of filled seed and therefore low germination, the proportion of hybrids is generally low and also highly fluctuating between years. This has been revealed by a few studies using biochemical markers first (BERGMANN and RUETZ, 1987; Braun, 1990; HäCKER and BERgMANN, 1991; ENNOS and QIAN, 1994) and more recently molecular markers (ACHERÉ, 1999; SCHEEPERS et al., 2000; ACHERÉ et al., 2004).

As a result, reforestation with so-called 'hybrid' larch has been done so far in an uncontrolled way, with varying mixtures of hybrid plants and either European or Japanese larches or both. The possibility to individually identify taxa and from a practical point of view, to sort out hybrids out of nursery benches prior to plantation, is obviously attractive for experimental purposes but also for commercial plantations where product homogeneity is sought for.

Although reliable, diagnostic molecular markers developed so far are too expensive to be used for routine sorting whereas morphological markers would be $a$ priori better suited. However, sorting based on morphological markers is rather complex in this context for at least four reasons: firstly because of the young age of the material to be identified (1-3 yrs old seedlings) whereas the botanical description and classification of the Larix species rely mostly on mature tree characteristics (PATsChKe, 1913; Ostenfeld and LARSEN, 1930); secondly, because European and Japanese larches appear closely related both taxonomically and genetically (SEMERIKov et al., 2003; WeI and WANG, 2003); thirdly, because seedlings to be identified have closely related pedigrees (pure species and hybrid siblings share common parents); and fourthly, because the parental clones used in the various seed orchards may cover a wide range of the species natural genetic variability.

In the 1940s, LAING (1944) conducted one of the most detailed studies on Larix species in which he examined several morphological features of flowers, cones, buds, leaves and bark as well as some anatomical traits of leaves and wood. Besides mature tree features (flowers, cones, bark), the most pertinent traits included anatomical parameters of the leaves (structure of the epidermis, number of cells of the endodermis, resin canals of the pulvinus) and of the wood (resin canals and height of fusiform rays) and finally, the colour of the roots. While effective in discriminating taxa when used in combination, these traits impose destructive observations of the plants and they can not be observed without the help of 
a microscope, which is hardly compatible with routine sorting of seedlings in nurseries.

Surprisingly, while much progress has been recently made with molecular markers to identify individual taxa and consequently to determine hybrid purity in seed or seedling lots (ACHERÉ et al., 2004; GROS-LOUIS et al., 2005), no taxonomic studies have been conducted on morphological markers since Laing's study.

The objective of this study is therefore to search for new phenotypical (morphological and adaptive) traits discriminating European and Japanese larches and their hybrids, that are non-destructive and applicable on young seedlings, and easily accessible for routine identification needs.

\section{Material and Methods \\ Material}

Two sets of plants were raised for this study. The first one (called 'evaluation set') was used to characterise the different taxa and to search for discriminant traits. The second one ('validation set') was used to confirm their effectiveness. Indeed, our concern was that strong environmental effects (like climate, soil, nursery handling) might affect the expression of taxa characteristics and could somehow invalidate the selected discriminant traits.

\section{'Evaluation set' material}

Seedlings derived from six seed lots collected in five commercial hybridisation seed orchards (Table 1a). They represent various types of orchards in terms of their genetic composition (origin and number of clones), establishment design and way of crossing (ELxJL or

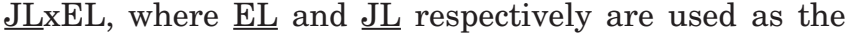

female parents) and of cone collection (one or both parents). Their choice was conditioned by our wish to get a wide range of contrasting hybrid purity levels and taxa mixtures.

After a 5-week pre-treatment, the six seed lots were sown at the INRA nursery (Orléans) on May 3, 1999. Seedlings were raised in plastic boxes $(40 \times 60 \mathrm{~cm})$ with a mixed substratum of 75:25 peat:vermiculite ( $\mathrm{pH} 5.5)$ and placed in a plastic greenhouse. Five weeks after germination, seedlings were moved to a shade-house, from which the cover sheet was removed by mid-September. In 1999, the seedlings were individually labelled. On March 23 of the following year, they were lined out in nursery beds, following a randomised complete block (RCB) design with 4 blocks and 20-30 tree-linear plots.

'Validation set' material

Due to a lack of seed from the first set, a second sample of seed lots collected from six hybridisation seed orchards was used for the validation set (Table 1b). Their choice was based on similar criteria as for the first set. The 6 lots were sown in the same way as for the evaluation set on May 12, 2003 and seedlings were lined out in the same nursery on February 24, 2004 using a RCB design with 2 blocks and linear plots (variable numbers of seedlings per lot).

\section{Needles sampling and taxa determination}

On July 14, 2000 for the first set and on July 15, 2004 for the second set, needles were sampled from each seedling and stored at $-80^{\circ} \mathrm{C}$ before DNA extraction. Total DNA was isolated from $100 \mathrm{mg}$ of fresh needle tissue from each sample following the 'Qiagen Dneasy Kit' and then used for PCR reactions. Taxa identification was then done following ACHERÉ (1999) by using diag-

Table 1. - Characteristics of seed orchards $(\mathrm{EL}=L$. decidua; $\mathrm{JL}=L$. kaempferi).

\begin{tabular}{|c|c|c|}
\hline $\begin{array}{l}\text { Seed orchard } \\
\text { code }\end{array}$ & Crop year & Components ${ }^{1)}$ \\
\hline \multicolumn{3}{|c|}{ Type A: seed collection on EL } \\
\hline SO1 & 1992 & $1 \mathrm{EL} \times 1 \mathrm{FS} \mathrm{JL}^{2)}$ \\
\hline $\mathrm{SO} 3$ & 1983 & $\underline{\mathrm{EL}} \times 1 \mathrm{JL}$ \\
\hline $\mathrm{SO} 4$ & 1996 & $12 \mathrm{EL} \times 28 \mathrm{JL}$ \\
\hline \multicolumn{3}{|c|}{ Type B: seed collection on $J L$} \\
\hline SO5 & 1996 & $33 \mathrm{JL} \times 33 \mathrm{EL}$ \\
\hline \multicolumn{3}{|c|}{ Type C: seed collection on EL and $J L$} \\
\hline $\mathrm{SO} 2.1$ & 1987 & $15 \mathrm{JL} \times 15 \mathrm{EL}^{3)}$ \\
\hline $\mathrm{SO} 2.2$ & 1998 & $15 \mathrm{JL} \times 15 \mathrm{EL}^{3)}$ \\
\hline
\end{tabular}

b) Validation set (experiment 2003-2004)

\begin{tabular}{|c|c|c|c|}
\hline $\begin{array}{l}\text { Seed orchard } \\
\text { code }\end{array}$ & Crop year & Components $^{1)}$ & Comments \\
\hline \multicolumn{4}{|c|}{ Type A: seed collection on EL } \\
\hline SO7 & 1996 & $\underline{1 \mathrm{EL}} \times 5 \mathrm{JL}$ & Subset of clones from $\mathrm{SO} 4$ \\
\hline SO9 & 1996 & $1 \mathrm{EL} \times 261 \mathrm{JL}$ & - \\
\hline SO10 & 1999 & $\underline{1 \mathrm{EL} \times} 1 \mathrm{FS} \mathrm{JL}^{2)}$ & $\begin{array}{l}\text { Same female parent and nearly the same genetic } \\
\text { composition as in SO1 for male parents but with } \\
\text { supplemental mass-pollination }\end{array}$ \\
\hline \multicolumn{4}{|c|}{ Type B: seed collection on JL } \\
\hline $\mathrm{SO} 2.3$ & 1983 & $\underline{15 \mathrm{JL}} \times 15 \mathrm{EL}$ & $\begin{array}{c}\text { Same orchard as } \mathrm{S} 02.1 \text { and } \mathrm{SO} 2.2 \text { in the } \\
\text { evaluation set }\end{array}$ \\
\hline SO6 & 1996 & $20 \mathrm{JL} \times 20 \mathrm{EL}$ & $\begin{array}{l}\text { Some common clones with SO5: } \\
8 \text { for EL and } 12 \text { for JL }\end{array}$ \\
\hline SO8 & $1993-2002$ & $1 \mathrm{JL} \times 4 \mathrm{EL}$ & Mixed crops from several years \\
\hline
\end{tabular}


nostic cytoplasmic DNA markers developed by SCHEEPERS et al. (2000) and ACHERÉ et al. (2004). The first one, $f-13$, a mitochondrial sequence, is maternally inherited while the second one, $l l$-Taq1 from the chloroplast genome is paternally inherited. Both show interspecific polymorphisms. Their combination efficiently allows identification of the two pure species and also the two hybrid combinations: ELxJL vs JLxEL.

\section{Observations and measurements}

All together 21 different parameters were recorded on each seedling of the evaluation set from winter 1999/2000 until winter 2000/2001. They included: i) phenological traits such as leaf retention (marcescence), bud flushing, bud setting and autumn yellowing of needles; ii) growth traits like total height, stem root collar diameter and lamma shoot formation; iii) architecture traits such as taper, numbers of sylleptic and of proleptic shoots; and iv) needle and bark colours.

Traits were intentionally chosen for the relative simplicity of their evaluation and they were either measured or subjectively scored. A short description of traits together with the timing of their assessment is given in Table 2.

Regarding bud flushing, observations were conducted on the terminal bud at 4 different dates, using a 5-scale subjective scoring system. In addition, sub-terminal buds among the five upper ones, which had reached stage 3 were counted at each of the 4 dates. The data used in the analysis corresponded to scores at the date when the average score on all seedlings was closest to stage 3 . The number of days (from January $1^{\text {st }}$ ) to get terminal bud flushing (stage 3 ) was also computed. For terminal bud setting, observations were conducted at 9 different dates. The 'bud setting' variable used for the analysis corresponded to the number of days (from August $10^{\text {th }}$ ) required by each seedling to form a dor- mant bud. Needle (upper and lower faces) and stem bark colours were determined using the Munsell colour charts for plant tissues and soils respectively. For needles, plate 7.5GY was systematically used. For each seedling, ten needles picked at mid-length of a twig located at mid-height (same orientation) were examined in the laboratory under artificial light. Average chroma (saturation) and value (lightness) were determined for each face separately. Special care was taken to handle needles without removing their bloom. For colour determination of bark, 4 different combinations were judged sufficient namely from Munsell plates 2.5Y, 7.5YR, 10YR and 2.5YR. Only the bark of stem and branches of current annual increments were observed and it was necessary to wait until plants were fully dormant to get a stabilised colour.

For the validation set, the traits were assessed according to the same methodology and following the timetable provided in Table 2. The traits were mostly the same but observations on 1-yr old seedlings were reduced.

\section{Statistical analysis}

Descriptive statistics were computed for each taxon within orchards and over all orchards. Two-way analyses of variance were conducted on quantitative traits to detect differences among taxa; when all 3 taxa were present among the progeny of an orchard, a SCHEFFÉ-test was used to compare taxa means. $\log (\mathrm{x}+1)$ data transformations were applied on some variables (SY, PR) to normalise them. Log-linear analyses were used for qualitative traits.

The traits showing significant differences among taxa $(p=0.05)$ in at least 2 different orchards and not too closely correlated to each other, were included in several multivariate linear discriminant analyses (LDA) at the orchard level first, then over all orchards. For practical

Table 2. - Description of traits observed and measured during the $1^{\text {st }}$ and $2^{\text {nd }}$ growing seasons (evaluation and validation sets).

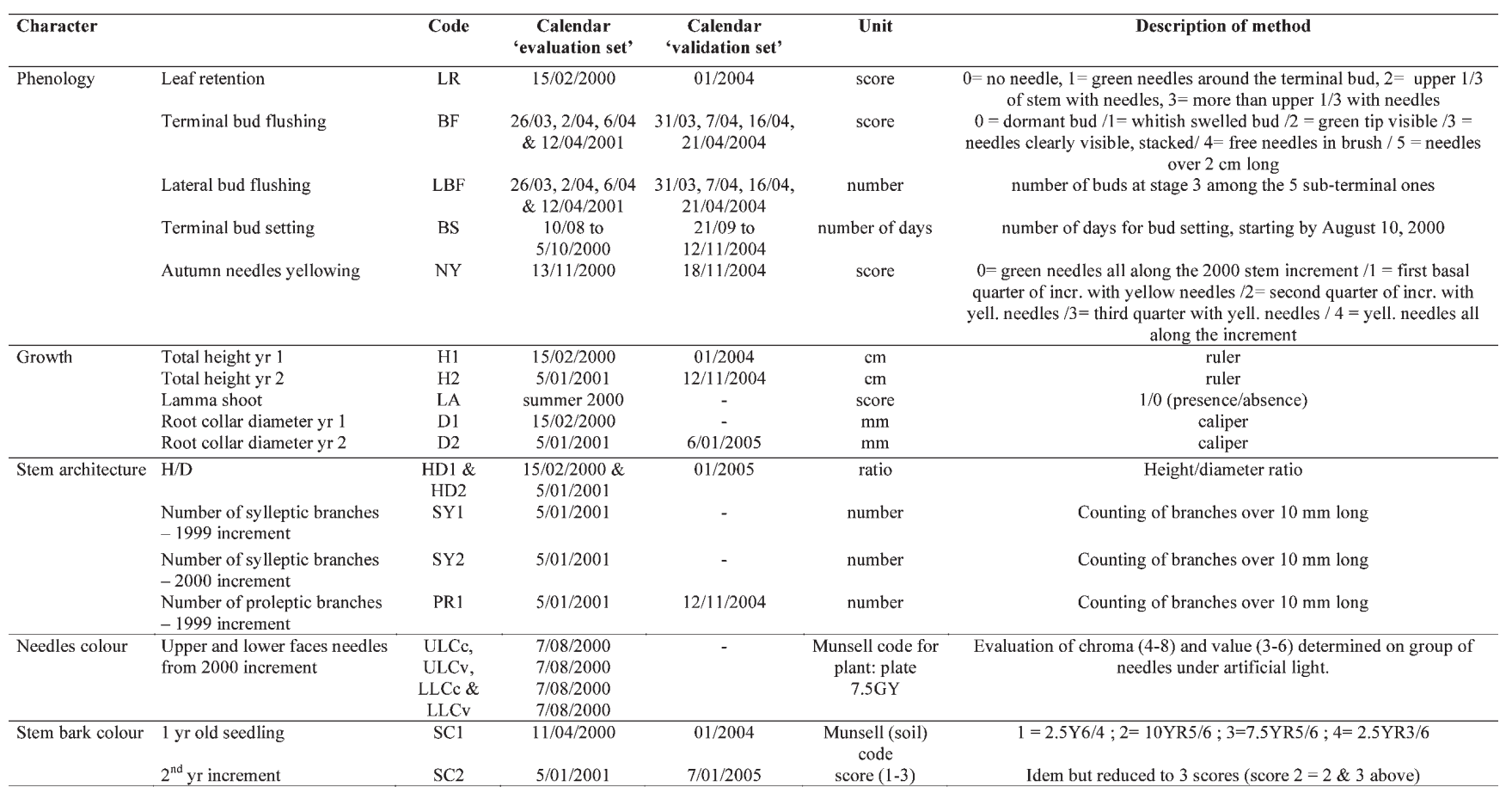


purposes, we favoured too traits which could be easily measurable. The SPSS statistical software package (version 13.0 for Windows, SPSS Inc.) was used for these analyses. LDA is a supervised pattern recognition technique where the data are separated into defined groups before analysis. In our study, groups corresponded to taxa as determined by molecular markers.

Linear combinations that showed the greatest square differences between groups relative to the variance within groups defined discriminant functions. The quality of fit of the discriminant model to the data was judged through the canonical correlation coefficient, and the Wilks' Lambda parameter was used to evaluate the discrimination ability of functions. The adequacy of discriminant functions was evaluated through their efficiency to correctly classify individuals into taxa, including a cross-validation procedure. With the latter, each case is classified using a discriminant function based on all cases except the given case. The relative weight of traits in the discriminating functions was appreciated through the standardised canonical discriminant function coefficients. Details on LDA can be found for example in Saporta (1990) or HUBERTY (1994).

The data from the validation set were analysed in the same way to confirm the main taxa features and the interest of particular traits for taxa identification.

\section{Results}

Taxa determination of seedlings by molecular markers

The taxon of all surviving seedlings was assessed during the second growing season using the diagnostic mol- ecular markers (Table 3). Hybrid purity of seedling lots showed a high variability ranging from $17.0 \%$ (SO3) up to $77.7 \%$ (SO4) for the evaluation set and from 8.2 (SO6) up to $91.8 \%$ (SO10) for the validation set. Depending on the orchards and method of cone collection, hybrids were either of the ELxJL type (SO1, SO3, SO4) or of the JLxEL type (SO5) or of both types (SO2). As a result, pure species rates were also very variable with extreme lots consisting mostly of European larch like SO3 or of Japanese larch like SO5 and SO6.

Interestingly, hybrid rates determined in seedling lots were most often higher than those observed in seedlots (Table 3), a phenomenon already noticed and confirmed by our previous studies. Besides possible differences due to the precision of the hybrid proportion estimates (size of samples), a low viability of pure species selfed-progenies in some orchards and/or a species-related response to some pathogens might also explain that increase. Indeed in our environmental conditions, Japanese larch seems more prone to damage by damping-off than European and hybrid larches. In contrast, damage by larch needle cast (Meria laricis) is more frequent and severe on European larch compared to the two other taxa. However, this hypothesis was not experimentally checked for in this study.

In addition to the well-known effect of the crop year on hybrid purity (SO2), some unexpected taxa were detected in the composition of some orchards progenies like the presence of ELxJL seedlings in SO5, of JLxEL hybrids among SO3 seedlings or in the seed lot of SO4. When detected, these individuals were discarded before further analysis.

Table 3. - Proportion of taxa in orchard seed and/or seedling lots.

a) Evaluation set

\begin{tabular}{|c|c|c|c|c|c|c|c|}
\hline \multirow[t]{2}{*}{ Seed orchard } & \multirow{2}{*}{$\begin{array}{l}\text { Nber of } \\
\text { seed or } \\
\text { seedlings }\end{array}$} & \multirow[t]{2}{*}{ Test on } & \multicolumn{4}{|c|}{$\begin{array}{c}\text { Proportion of taxa } \\
(\%)\end{array}$} & \multirow{2}{*}{$\begin{array}{c}\text { Hybrid } \\
\text { purity } \\
(\%)\end{array}$} \\
\hline & & & EL & ELxJL & JLXEL & $\mathrm{JL}$ & \\
\hline \multicolumn{8}{|c|}{ Type A: seed collection on EL } \\
\hline SO1 & 81 & $\mathbf{P}$ & 28.4 & 71.6 & 0 & 0 & 71.6 \\
\hline & 200 & s & $-1)$ & \multicolumn{2}{|c|}{49.3} & $-1)$ & 49.3 \\
\hline \multirow[t]{2}{*}{$\mathrm{SO} 3$} & 131 & $\mathrm{P}$ & 82.1 & 15.2 & 1.8 & 1.0 & 17.0 \\
\hline & 200 & $\mathrm{~s}$ & $-{ }^{1)}$ & \multicolumn{2}{|c|}{13.6} & $-1)$ & 13.6 \\
\hline \multirow[t]{2}{*}{ SO4 } & 118 & $\mathrm{P}$ & 22.3 & 77.7 & 0 & 0 & 77.7 \\
\hline & 200 & $\mathrm{~S}$ & 32.0 & 66.5 & 1.5 & 0 & 68.0 \\
\hline \multicolumn{8}{|c|}{ Type B: seed collection on JL } \\
\hline \multirow[t]{2}{*}{ SO5 } & 99 & $\mathrm{P}$ & 0 & 1.3 & 21.1 & 77.6 & 22.4 \\
\hline & 200 & $\mathrm{~s}$ & 0 & 0.0 & 22.5 & 77.5 & 22.5 \\
\hline \multicolumn{8}{|c|}{ Type $C:$ seed collection on $E L$ and $J L$} \\
\hline \multirow[t]{2}{*}{ SO2.1 } & 170 & $\mathrm{P}$ & 26.6 & 23.1 & 18.2 & 32.2 & 41.3 \\
\hline & 205 & $\mathrm{~s}$ & 30.2 & 19.5 & 16.1 & 34.2 & 35.6 \\
\hline \multirow[t]{2}{*}{$\mathrm{SO} 2.2$} & 160 & $\mathrm{P}$ & 28.9 & 21.7 & 26.3 & 23.0 & 48.0 \\
\hline & 205 & $\mathrm{~s}$ & 22.4 & 24.9 & 22.4 & 30.2 & 47.3 \\
\hline
\end{tabular}

b) Validation set

\begin{tabular}{lccccccc}
\hline Seed orchard & $\begin{array}{c}\text { Nber of } \\
\text { seedlings }\end{array}$ & Test on & \multicolumn{3}{c}{$\begin{array}{c}\text { Proportion of taxa } \\
\text { (\%) }\end{array}$} & \multicolumn{2}{c}{$\begin{array}{c}\text { Hybrid } \\
\text { purity } \\
\text { (\%) }\end{array}$} \\
\hline Type A: seed collection on $E L$ & & EL & ELxJL & JLxEL & JL & \\
SO7 & 107 & $\mathrm{P}$ & 15.9 & 84.1 & 0 & 0 & 84.1 \\
SO9 & 87 & $\mathrm{P}$ & 12.5 & 87.5 & 0 & 0 & 87.5 \\
SO10 & 110 & $\mathrm{P}$ & 8.2 & 91.8 & 0 & 0 & 91.8 \\
\hline Type B: seed collection on JL & & & & & & \\
SO2.3 & 102 & $\mathrm{P}$ & 3.9 & 6.9 & 16.6 & 72.6 & 23.5 \\
SO6 & 110 & $\mathrm{P}$ & 0 & 0 & 8.2 & 91.8 & 8.2 \\
SO8 & 65 & $\mathrm{P}$ & 0 & 0 & 73.8 & 26.2 & 73.8 \\
\hline
\end{tabular}

$\mathrm{S}=$ seed $/ \mathrm{P}=$ plantlets (2 yr-old seedlings).

1) not available because tested only with isozymes. 
Table 4. - Means of species (within orchards) for phenology, growth, architecture, needles and bark colour traits. (Evaluation set).

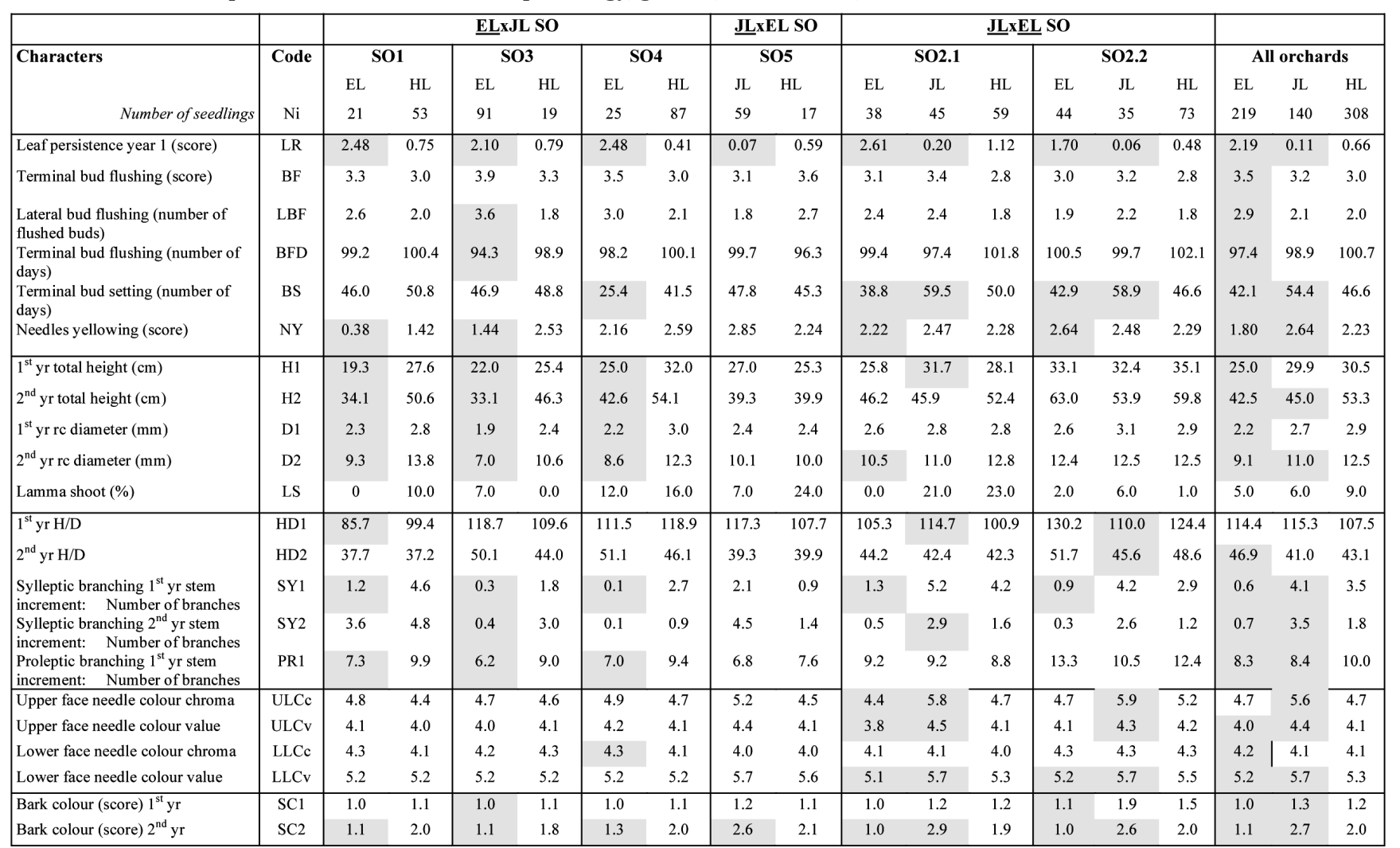

(in gray, when parental species are significantly different from the hybrid at $5 \%$ ).

In any case, our sampling of seed orchard lots was obviously appropriate for the purpose of this study as they represented well various proportions of taxa.

\section{Mean taxa characteristics}

Mean characteristics of individual taxa within orchard are given in Table 4 for the evaluation set. Comparison among taxa was based on 5 lots (4 orchards) for European larch vs hybrid larch, on 3 lots ( 2 orchards) for Japanese larch vs hybrid larch and finally on 2 lots (1 orchard) for a joint comparison of the 3 taxa.

Although the origins of clones in the orchards are variable and highly significant differences among orchards were observed for nearly all traits (ANOVA and logfunction not shown), some consistent characteristics of taxa can be seen in young seedlings.

\section{Phenological traits}

During winter following the first growing season, EL seedlings typically retained their leaves on the upper third (or even more) of the stem while JL seedlings lost nearly all their needles. The hybrid showed intermediate needle retention and frequently maintained a crown of needles around the terminal bud. Both pure species consistently and significantly differed from the hybrid for that trait.

For bud flushing, no significant differences among taxa were observed (except for SO3). Nevertheless, it was noted that bud flushing tended to be delayed slightly in hybrid larch compared to pure species (1-4 days later on average to reach the score 3 ).
Whatever the orchard, hybrid seedlings set bud prior to JL (2-12 days before) but after EL (2-16 days later); however these differences were not always significant. Autumn needle yellowing was more consistently significant among taxa. Compared to hybrid larch, EL usually kept its needles green on a larger portion of the stem (except for SO2.2) while JL seedlings got yellow needles earlier in the season and on a larger portion of the annual increment.

\section{Growth}

Compared to EL, hybrid larch was more vigorous in height and diameter both at the end of the first and of the second growing seasons. Highly significant differences were observed in many cases except for $\mathrm{SO} 2.2$. Apart from this latter lot, the hybrid superiority for total height at the end of the $2^{\text {nd }}$ growing season ranged from $13.4 \%$ (SO2.1) up to $48.4 \%$ (SO1) and for root collar diameter from $21.9 \%$ (SO2.1) up to $51.4 \%$ (SO3). Conversely, no significant differences were found between Japanese and hybrid larch.

Overall, hybrid larch seemed to be more prone to polycyclism than the pure species as indicated by a higher frequency of lamma shoots (up to $24 \%$ of stems for SO5) but the differences were not significant and some exceptions were observed (SO3, SO2.2).

\section{Stem form and branching pattern}

No consistent trend was observed for stem taper at the end of the first or second growing seasons (HD1 and HD2) as results varied according to orchards. 
Branching habit, and more precisely the number of sylleptic shoots on 1- and 2-yr old seedlings (SY1) as well as the number of proleptic branches on the $1^{\text {st }} \mathrm{yr}$ stem increment (PR1), differentiated taxa much better. European larch had far fewer sylleptic shoots than hybrid larch in both years. For example, at the end of the $1^{\text {st }}$ year, this number ranged from 0.1 to 1.3 for EL compared to 1.8 to 4.6 for HL according to orchards and all the differences were significant. In all cases, JL showed the highest number of sylleptic shoots in both years. Furthermore, hybrid larch usually produced significantly more proleptic shoots than EL but it never differed from JL.

As a whole, EL appeared very often slender compared to HL and JL because of a slightly higher taper and of less branches.

\section{Colour of needles, stem and twigs}

Except for the SO2 orchard, the colours of the upperand lower-faces of needles were very similar whatever the taxa. In SO2, both pure species differed significantly from the hybrid. In particular, JL needles had the highest chromas (saturation) and the highest values (lightness) both on the upper and lower faces. The same trend was also observed for SO5 orchard. For EL, these values were either not significantly different from those of the hybrid or significantly lower. Except for the upper-needle-face value, EL differed significantly from JL for the other needle colour parameters with lower chromas and values.

While few differences were observed among taxa for stem bark colour on 1-yr old seedlings, taxa clearly showed highly significant differences for that trait on 2 yr old seedlings whatever the orchard. European larch had the lightest bark colour (yellowish) while at the other extreme, JL had the most reddish bark. The hybrid was clearly intermediate.

\section{Within taxa variability}

Significant differences among taxa were evident for several traits. Yet, even though mean characteristics of pure species were fairly well contrasted, the hybrid was intermediate for many traits and therefore similar to one or the other pure species depending on the trait. In addition, a large variability among individual seedlings within taxa was also observed as illustrated for major traits in Figure 1. As can be seen, the ranges of variables for all three taxa were largely overlapping and
LR

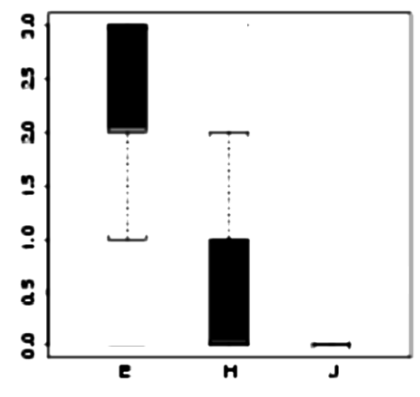

He

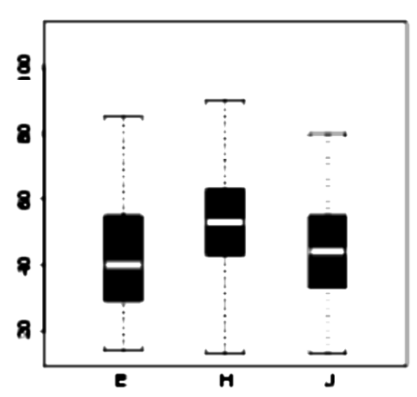

PR1

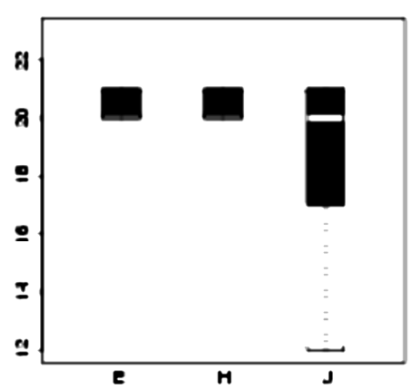

BF

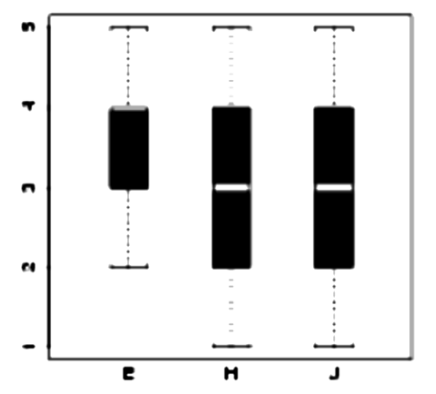

D2

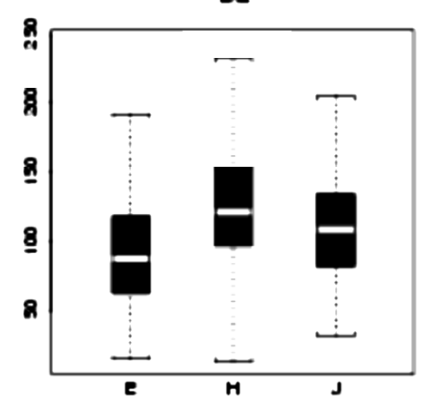

$5 \mathrm{~S} 2$

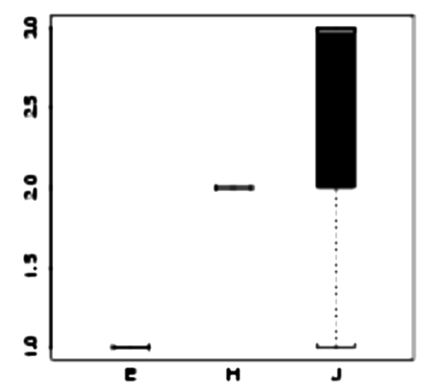

NY

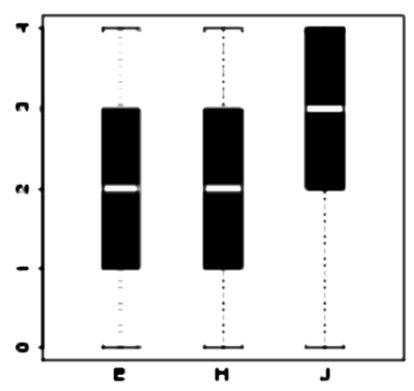

HD2

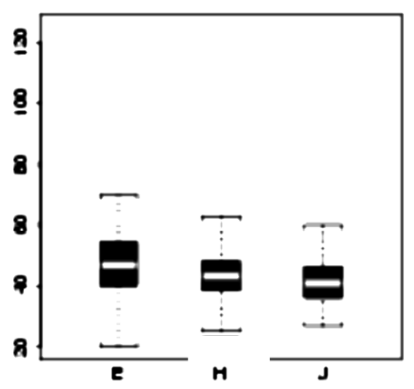

ULC

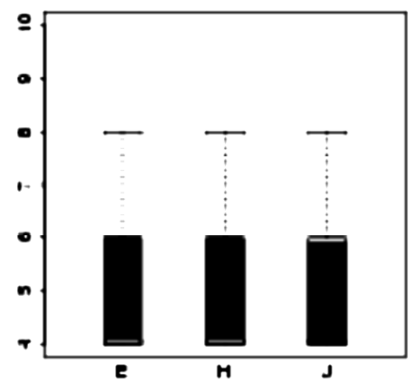

BS

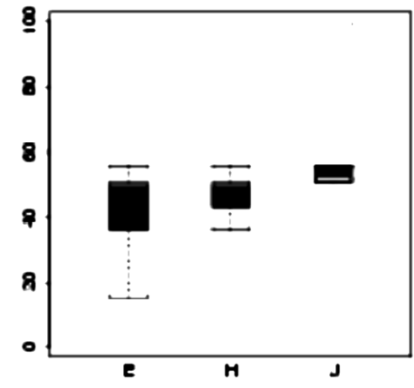

SY2

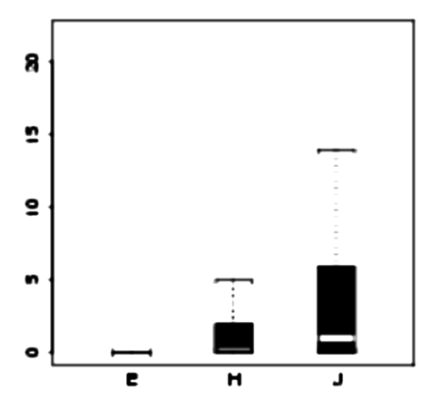

ULCr

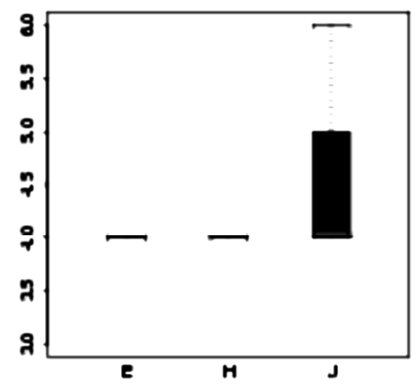

Figure 1. - Boxplot diagram for some traits of the evaluation set (all orchards confounded). (Traits coded as in Table 2; E = EL, $\mathrm{J}=\mathrm{JL}$ and $\mathrm{H}=\mathrm{HL}$ ). The median is indicated by the white line, the dark box represents the inter-quartile range (IQR); the extreme values (within 1.5 times the IQR) are at the end of the lines extending from the IQR. 
Table 5. - Linear discriminant analysis (in bold, the three variables per function with highest correlation coefficients with discriminant functions).

\begin{tabular}{|c|c|c|c|c|c|c|c|c|c|c|}
\hline & \multicolumn{3}{|c|}{ EL $x$ JL SO } & JLxEL SO & \multicolumn{4}{|c|}{$\underline{\mathbf{J L}} \times \underline{\text { EL SO }}$} & \multirow{2}{*}{\multicolumn{2}{|c|}{ All orchards }} \\
\hline & SO1 & SO3 & SO4 & SO5 & & & & & & \\
\hline \multicolumn{11}{|c|}{ Correlations between discriminating variables and standardised canonical discriminant functions } \\
\hline & & & & & $1^{\text {st }} \mathrm{fet}$ & $2^{\text {nd }} \mathrm{fct}$ & $1^{\text {st }} \mathrm{fct}$ & $2^{\text {nd }} \mathrm{fct}$ & $1^{\text {st }}$ fet & $2^{\text {nd }} \mathrm{fct}$ \\
\hline $\mathrm{SC} 2$ & 0.904 & 0.755 & -0.489 & 0.578 & 0.941 & 0.012 & 0.829 & -0.056 & 0.879 & 0.164 \\
\hline LR & -0.213 & -0.487 & 0.888 & -0.445 & -0.519 & 0.550 & -0.473 & 0.367 & -0.559 & 0.488 \\
\hline SY1 ${ }^{1)}$ & 0.117 & 0.297 & -0.316 & 0.178 & 0.174 & -0.329 & 0.203 & -0.006 & 0.230 & -0.362 \\
\hline SY2 ${ }^{1)}$ & -0.027 & 0.302 & -0.112 & 0.385 & 0.142 & -0.061 & 0.173 & 0.288 & 0.168 & 0.192 \\
\hline BS & 0.001 & 0.031 & -0.306 & 0.305 & 0.205 & -0.068 & 0.143 & 0.482 & 0.141 & 0.271 \\
\hline NY & 0.125 & 0.228 & -0.107 & 0.307 & 0.037 & 0.008 & -0.033 & 0.279 & 0.125 & 0.062 \\
\hline PR1 & 0.109 & 0.245 & -0.194 & -0.079 & 0.021 & 0.125 & -0.101 & -0.214 & 0.037 & -0.388 \\
\hline $\mathrm{H} 2$ & 0.125 & 0.308 & -0.207 & 0.098 & -0.012 & -0.498 & -0.115 & -0.173 & 0.076 & -0.569 \\
\hline D2 & 0.120 & 0.354 & -0.271 & 0.140 & 0.024 & -0.628 & 0.014 & 0.063 & 0.154 & -0.592 \\
\hline Canonical correlation & 0.970 & 0.820 & 0.839 & 0.640 & 0.905 & 0.332 & 0.883 & 0.324 & 0.878 & 0.380 \\
\hline $\begin{array}{l}\% \text { of variance } \\
\text { explained by function }\end{array}$ & 100 & 100 & 100 & 100 & 97.3 & 2.70 & 96.8 & 3.2 & 95.2 & 4.8 \\
\hline Wilks'lambda & 0.058 & 0.328 & 0.295 & 0.590 & 0.161 & 0.889 & 0.197 & 0.895 & 0.196 & 0.855 \\
\hline \multicolumn{11}{|c|}{ Proportion of correctly classified individuals (\%) } \\
\hline Original classification & 98.6 & 94.1 & 95.5 & 86.6 & \multicolumn{2}{|c|}{85.9} & & & \multicolumn{2}{|c|}{85.7} \\
\hline EL & 94.7 & 95.2 & 91.7 & - & \multirow{2}{*}{\multicolumn{2}{|c|}{$\begin{array}{l}97.2 \\
90.5\end{array}$}} & & & \multicolumn{2}{|c|}{94.6} \\
\hline $\mathrm{JL}$ & - & - & & 94.0 & & & & & \multirow{2}{*}{\multicolumn{2}{|c|}{$\begin{array}{l}71.4 \\
85.5\end{array}$}} \\
\hline HL & 100 & 89.5 & 96.5 & 64.7 & \multicolumn{2}{|c|}{75.4} & & & & \\
\hline Cross-validation & 98.6 & 92.2 & 91.8 & 73.1 & \multicolumn{2}{|c|}{83.7} & & & \multicolumn{2}{|c|}{85.4} \\
\hline EL & 94.7 & 95.2 & 91.7 & - & \multicolumn{2}{|c|}{94.4} & & & \multicolumn{2}{|c|}{94.6} \\
\hline $\mathrm{JL}$ & - & - & - & 88.0 & \multirow{2}{*}{\multicolumn{2}{|c|}{$\begin{array}{l}88.1 \\
73.7\end{array}$}} & & & \multirow{2}{*}{\multicolumn{2}{|c|}{$\begin{array}{l}71.4 \\
84.9\end{array}$}} \\
\hline $\mathrm{HL}$ & 100 & 78.9 & 91.9 & 29.4 & & & & & & \\
\hline
\end{tabular}

1) based on log transformed data $(\ln (\mathrm{x}+1))$.

therefore no single trait was discriminant enough to accurately identify the taxa.

\section{Taxa discrimination}

Based on individual taxa identification with molecular markers, a linear discriminant analysis was conducted in order to evaluate the discriminating efficiency of variables when combined. Considering the previous results from variance analysis, 9 out of 21 traits were retained for that analysis. They were leaf retention (LR), bud setting (BS), total height (H2) and root-collar diameter (D2), sylleptic (SY1 and SY2) and proleptic (PR1) branching, bark colour (SC2) and needle yellowing (NY). Intentionally, the traits which were selected had also to remain quite easily measurable in the nursery.

As shown in Table 5, the linear discriminant functions calculated for each orchard were quite effective in classifying individuals into taxa. Except for the orchard SO5, the canonical correlations were high, ranging from 0.82 up to 0.97 and the Wilks'lambda parameters were low showing a great discriminating ability.

Among the 9 traits used in the analyses, two emerged weighing heavily in discriminating taxa, namely SC2 (bark colour) and LR (leaf retention). Their correlation coefficients with the discriminant functions were systematically among the highest in absolute value for all orchards. Good correlations were also observed with other traits but not so consistently.

Classification results with the discriminant functions calculated at the orchard level are shown in Table 5. Depending on orchards, $86 \%$ to $99 \%$ of individuals were properly classified. The best results were obtained in orchards where progenies included only EL and HL, namely the SO1, SO3 and SO4 seedling lots where $94 \%$ to $99 \%$ of the individuals were correctly classified. In the three other lots where JL was present (SO2, SO5), this figure went down to around $86 \%$. Similar results, but of course a bit less optimistic, were obtained from the cross-validation.

For these three latter lots (SO5, SO2.1 and SO2.2), more than $94 \%$ of EL seedlings (when they occurred) were correctly classified, the confusion being mostly between JL and HL. In that respect, particularly poor results were observed for the SO5 lot where only $29 \%$ of hybrids were properly identified. This result is due to special circumstances and will be discussed later.

In an attempt to find a unique discriminant model, a second analysis was conducted on individuals over all 6 orchard lots. In that case, LR and SC2 but also H2 and D2 proved to have a heavy weight in the discriminating functions. More than $85 \%$ of the individuals were correctly classified and as mentioned before, there were classification problems for HL but above all for JL (about $71 \%$ correctly identified).

Two additional discriminant analyses were performed with the aim to reduce even more the number of traits to be observed. In the first one, LR, SC2 and H2 were included; in the second one, only LR and SC2 were considered. The classification results of the new computed discriminant functions are presented in Table 6. Obviously no loss in the discriminating ability could be observed. Only 2 variables (LR and SC2) proved to be as 
Table 6. - Simplified discriminant analysis (evaluation set): proportion of correctly classified individuals. a)

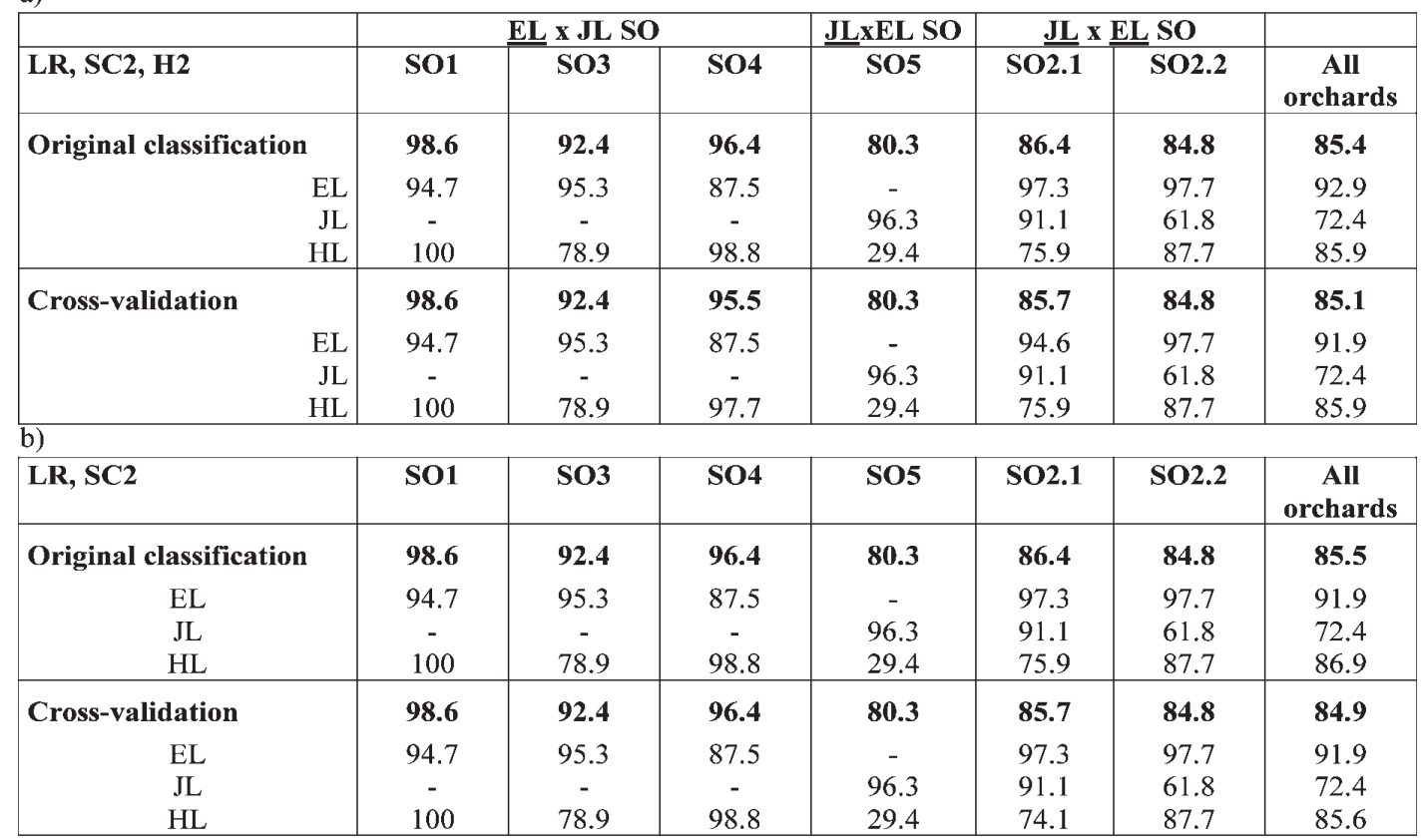

a) when LR (leaf retention), SC2 (bark colour, age 2) and H2 (total height, age 2) are considered,

b) when LR and SC2 only are considered.

efficient as or even better than the whole set of variables. This was particularly clear for SO5 progeny for which correct classification percentage increased from 73.1 up to more than $80 \%$, but in that case again, the majority of hybrids were not properly classified.

Finally, we compared the efficiency of the discriminant functions ${ }^{1}$ obtained from the whole data-set with that calculated from each separate orchard data-set. For SO1, SO2.1 and SO2.2 seedling sets, the classification of individuals was rigorously the same; for SO3, 1 hybrid individual wrongly classified at the orchard level, was correctly classified with the whole set functions; for SO4, 1 hybrid, determined as a Japanese larch at the orchard level was correctly classified but 4 European larches were wrongly classified as hybrids; for SO5, 17 Japanese larches were wrongly classified while 8 hybrids were correctly identified. So, for the whole population, 11 additional misclassification could be attributed to the use of functions obtained from the whole data-set, reducing the percentage of correctly identified individuals by only $2 \%$.

\section{Validation set results}

Growth conditions and seedlings performances contrasted considerably between the evaluation and the validation sets, which was an unpredictable but desired condition for the validation of previous results. Firstly, bud flushing and bud setting occurred much later in the validation set than in the evaluation set. According to taxa, the delay ranged from about 10 to 17 days for bud flushing and from 21 to 30 days for bud setting (Table 7 ). Secondly, the individuals of the validation set were

\footnotetext{
1) For EL: $-11.014+9.446 * \mathrm{SC} 2+4.476 * \mathrm{LR}$

For JL: $-29.794+20.692 * \mathrm{SC} 2+1.961 * \mathrm{LR}$

For HL: $-16.565+15.313 * \mathrm{SC} 2+2.419 * \mathrm{LR}$
}

more vigorous than those of the evaluation set. At the end of the 2 nd year, they were 7 to $46 \%$ taller and 9 to $19 \%$ thicker according to taxa. Thirdly, 2 yr-old seedlings from the validation set appeared more slender and with many more branches (8-17 against 1-4 for sylleptic branches) when compared to those from the evaluation set.

Despite obvious growth condition differences and a strong orchard effect, the major trends of taxa features found in the evaluation set were mainly confirmed in the validation set. Indeed, the results presented in Table 7 confirmed the extreme features of EL and JL for leaf retention, number of sylleptic branches and bark colour, the particular behaviour of EL for terminal bud setting (earlier) and yellowing of needles (delayed) compared to JL and HL, and the delayed terminal bud flushing for HL (more than 10 days for several orchards) compared to pure species.

Again the taxa could not be identified using any single trait and the data were analysed using LDA (Table 8). Together with single trait analysis, results from the discriminant analysis corroborated those found in the evaluation set: that is the heavy weight of leaf retention and bark colour and conversely, the relatively low weight of needle yellowing, bud setting and branching in discriminating functions. However, the contributions of growth traits and, to a lesser extent, of bud flushing were more pronounced. It is also worthwhile to note that as in the evaluation set, misclassification of hybrids was more frequent in orchards where JL acts as the mother species (SO2.3, SO6, SO8).

Reducing the set of observations to LR, SC2 and H2 or simply to LR and SC2 proved, as for the evaluation set, valid for correctly identifying hybrids, except for SO2.3 when $\mathrm{H} 2$ was not used (results not shown). 
Table 7. - Means of species (within orchards) for phenology, growth, architecture and bark colour traits (validation set).

\begin{tabular}{|c|c|c|c|c|c|c|c|c|c|c|c|c|c|c|c|c|}
\hline \multirow{3}{*}{$\begin{array}{l}\text { Characters } \\
\text { Number of seedlings }\end{array}$} & \multirow{3}{*}{$\begin{array}{c}\text { Code } \\
\text { ni }\end{array}$} & \multicolumn{6}{|c|}{ EL x JL SO } & \multicolumn{6}{|c|}{ JL x EL SO } & \multirow{2}{*}{\multicolumn{3}{|c|}{ All orchards }} \\
\hline & & \multicolumn{2}{|c|}{ SO7 } & \multicolumn{2}{|c|}{ SO9 } & \multicolumn{2}{|c|}{ SO10 } & \multicolumn{2}{|c|}{ SO2.3 } & \multicolumn{2}{|c|}{ SO6 } & \multicolumn{2}{|c|}{ SO8 } & & & \\
\hline & & $\begin{array}{l}\text { EL } \\
17\end{array}$ & $\begin{array}{c}\text { HL } \\
91\end{array}$ & $\begin{array}{l}\text { EL } \\
11\end{array}$ & $\begin{array}{l}\mathrm{HL} \\
77\end{array}$ & $\begin{array}{c}\text { EL } \\
9\end{array}$ & $\begin{array}{l}\mathrm{HL} \\
102\end{array}$ & $\begin{array}{l}J L \\
73\end{array}$ & $\begin{array}{l}\mathrm{HL} \\
27\end{array}$ & $\begin{array}{c}\mathrm{JL} \\
101\end{array}$ & $\begin{array}{c}\mathrm{HL} \\
9\end{array}$ & $\begin{array}{l}\mathrm{JL} \\
13\end{array}$ & $\begin{array}{l}\mathrm{HL} \\
53\end{array}$ & $\begin{array}{c}\mathrm{EL} \\
41^{1)}\end{array}$ & $\begin{array}{c}\mathrm{JL} \\
186\end{array}$ & $\begin{array}{l}\text { HL } \\
412\end{array}$ \\
\hline Leaf persistence year 1 (sc & LR & 2.4 & 1.0 & 1.6 & 0.8 & 2.1 & 1.1 & 0.3 & 1.0 & 0.8 & 1.6 & 0.9 & 1.0 & 2.1 & 0.6 & 1.0 \\
\hline Terminal bud & B & 2.9 & 2.0 & 3.1 & 1.8 & 3.0 & 2.2 & 1.1 & 2.4 & 2.7 & 3.0 & 2.4 & 2.2 & 2.9 & 2.1 & 2.2 \\
\hline $\begin{array}{l}\text { Lateral bud flu } \\
\text { flushed lateral }\end{array}$ & LBF & 3.8 & 3.3 & 4.2 & 3.4 & 4.0 & 3.4 & 3.1 & 3.6 & 3.7 & 4.1 & 3.6 & 3.5 & 3.9 & 3.5 & 3.5 \\
\hline $\begin{array}{l}\text { Terminal bud flushing (number } \\
\text { of days) }\end{array}$ & BFD & 111.4 & 122.4 & 97.8 & 117.5 & 109.4 & 120.2 & 124.0 & 111.1 & 112.3 & 109.4 & 112.4 & 117.9 & 107.5 & 116.0 & 116.6 \\
\hline $\begin{array}{l}\text { Terminal bud setting (number of } \\
\text { days) }\end{array}$ & BS & 57.6 & 66.7 & 85.1 & 83.3 & 86.6 & 88.0 & 84.6 & 76.6 & 71.3 & 62.1 & 62.4 & 65.9 & 72.7 & 76.0 & 75.9 \\
\hline Needles yellowing (score) & NY & 1.6 & 2.2 & 1.6 & 1.9 & 0.9 & 1.3 & 2.6 & 2.3 & 2.6 & 2.6 & 3.0 & 3.5 & 1.4 & 2.6 & 2.1 \\
\hline $1^{\text {st }} \mathrm{yr}$ total height $(\mathrm{cm})$ & $\mathrm{H} 1$ & 14.8 & 17.3 & 15.2 & 18.9 & 9.6 & 14.1 & 17.4 & 18.6 & 19.6 & 22.2 & 10.2 & 19.3 & 13.4 & 18.1 & 16.2 \\
\hline $2^{\text {nd }} \mathrm{yr}$ total height $(\mathrm{cm})$ & $\mathrm{H} 2$ & 46.0 & 62.0 & 54.4 & 70.1 & 35.9 & 58.2 & 58.2 & 72.3 & 76.5 & 78.9 & 33.5 & 62.7 & 45.4 & 65.9 & 64.2 \\
\hline $2^{\text {nd }} y r$ root collar diameter $(\mathrm{mm})$ & D2 & 9.8 & 13.3 & 10.9 & 14.0 & 9.5 & 12.2 & 11.3 & 14.2 & 15.1 & 16.2 & 8.6 & 13.5 & 9.9 & 13.1 & 13.1 \\
\hline $2^{\text {nd }} \mathrm{yr} \mathrm{H} / \mathrm{D}$ & HD2 & 46.5 & 46.8 & 51.4 & 50.8 & 38.3 & 47.3 & 52.6 & 51.9 & 51.1 & 49.4 & 38.4 & 45.7 & 46.4 & 50.5 & 49.1 \\
\hline $\begin{array}{l}\text { Sylleptic branching } 2^{\text {nd }} \text { yr stem } \\
\text { increment: Number of branches }\end{array}$ & SY2 & 1.5 & 11.9 & 13.6 & 15.0 & 11.0 & 12.8 & 15.6 & 13.2 & 19.0 & 10.3 & 7.6 & 5.5 & 7.7 & 16.8 & 13.5 \\
\hline Stem bark colour (score) $2^{\text {nd }} \mathrm{yr}$ & $\mathrm{SC} 2$ & 1.1 & 2.1 & 1.7 & 2.5 & 1.2 & 2.2 & 3.5 & 2.6 & 2.7 & 3.7 & 3.8 & 2.4 & 1.4 & 3.7 & 2.3 \\
\hline
\end{tabular}

(in gray, when parental species are significantly different from hybrid at $5 \%$ ).

1) includes 4 EL from SO2.3 orchard.

Table 8. - Linear discriminant analysis (Validation set).

\begin{tabular}{|c|c|c|c|c|c|c|c|c|c|}
\hline & \multicolumn{3}{|c|}{ EL $\times$ JL SO } & \multicolumn{4}{|c|}{ JL $x$ EL SO } & & \\
\hline & SO7 & SO9 & SO10 & \multicolumn{2}{|c|}{ SO2.3 } & SO6 & SO8 & \multicolumn{2}{|c|}{ All orchards } \\
\hline $\begin{array}{l}\mathrm{SC} 2 \\
\mathrm{LR} \\
\mathrm{BF} \\
\mathrm{NY} \\
\mathrm{H} 2 \\
\mathrm{D} 2\end{array}$ & $\begin{array}{c}\mathbf{0 . 5 0 9} \\
\mathbf{- 0 . 7 2 4} \\
-0.126 \\
0.124 \\
0.263 \\
\mathbf{0 . 3 3 3}\end{array}$ & $\begin{array}{c}\mathbf{0 . 4 4 7} \\
\mathbf{- 0 . 5 1 5} \\
\mathbf{- 0 . 3 3 1} \\
0.108 \\
0.295 \\
0.322\end{array}$ & $\begin{array}{c}\mathbf{0 . 6 4 9} \\
\mathbf{- 0 . 5 9 1} \\
-0.128 \\
0.238 \\
\mathbf{0 . 4 1 7} \\
0.296\end{array}$ & $\begin{array}{c}1^{\text {st }} \text { fct } \\
\mathbf{- 0 . 6 7 1} \\
\mathbf{0 . 8 1 0} \\
\mathbf{0 . 4 2 7} \\
-0.176 \\
0.159 \\
0.218\end{array}$ & $\begin{array}{c}2^{\text {nd }} \text { fct } \\
-0.232 \\
-\mathbf{0 . 3 9 8} \\
0.388 \\
0.090 \\
\mathbf{0 . 6 8 2} \\
\mathbf{0 . 6 3 2}\end{array}$ & $\begin{array}{c}\mathbf{0 . 8 2 5} \\
\mathbf{- 0 . 5 6 3} \\
\mathbf{- 0 . 1 3 3} \\
0.023 \\
-0.056 \\
-0.118\end{array}$ & $\begin{array}{c}\mathbf{0 . 8 1 6} \\
-0.133 \\
0.123 \\
-0.219 \\
\mathbf{- 0 . 5 5 6} \\
-\mathbf{0 . 5 4 7}\end{array}$ & $\begin{array}{c}1^{\text {st }} \text { fct } \\
\mathbf{0 . 8 8 6} \\
\mathbf{- 0 . 4 6 6} \\
-0.104 \\
\mathbf{0 . 2 2 0} \\
0.139 \\
0.105\end{array}$ & $\begin{array}{c}2^{\text {nd }} \text { fct } \\
0.420 \\
-0.128 \\
0.102 \\
-\mathbf{0 . 6 5 7} \\
\mathbf{- 0 . 5 1 4} \\
\mathbf{- 0 . 4 6 3}\end{array}$ \\
\hline Canonical correlation & 0.889 & 0.765 & 0.729 & 0.781 & 0.398 & 0.621 & 0.746 & 0.845 & 0.396 \\
\hline $\begin{array}{l}\% \text { of variance } \\
\text { explained by function }\end{array}$ & 100 & 100 & 100 & 89.3 & 10.7 & 100 & 100 & 93.1 & 6.9 \\
\hline Wilks'lambda & 0.210 & 0.414 & 0.469 & 0.328 & 0.842 & 0.614 & 0.444 & 0.241 & 0.843 \\
\hline \multicolumn{10}{|c|}{ Proportion of correctly classified individuals (\%) } \\
\hline Original classification & 98.0 & 95.2 & 98.1 & \multicolumn{2}{|c|}{90.8} & 95.3 & 93.4 & \multicolumn{2}{|c|}{89.8} \\
\hline EL & 87.5 & 72.7 & 88.9 & \multicolumn{2}{|c|}{$(75.0)$} & - & - & \multicolumn{2}{|c|}{74.4} \\
\hline $\mathrm{JL}$ & . & - & & \multicolumn{2}{|c|}{94.4} & 99.0 & 92.3 & \multicolumn{2}{|c|}{82.4} \\
\hline HL & 100.0 & 98.6 & 98.9 & \multicolumn{2}{|c|}{82.6} & 55.6 & 93.8 & \multicolumn{2}{|c|}{95.1} \\
\hline Cross-validation & 98.0 & 95.2 & 96.2 & \multicolumn{2}{|c|}{86.7} & 95.3 & 90.2 & \multicolumn{2}{|c|}{89.5} \\
\hline EL & 87.5 & 72.7 & 66.7 & \multicolumn{2}{|c|}{$(75.0)$} & - & - & \multicolumn{2}{|c|}{69.8} \\
\hline $\mathrm{JL}$ & - & - & - & \multicolumn{2}{|c|}{93.0} & 99.0 & 84.6 & \multicolumn{2}{|c|}{82.4} \\
\hline $\mathrm{HL}$ & 100.0 & 98.6 & 98.9 & \multicolumn{2}{|c|}{69.6} & 55.6 & 91.7 & \multicolumn{2}{|c|}{95.1} \\
\hline
\end{tabular}

(in bold, the three variables per function with highest correlation coefficients with discriminant functions).

\section{Discussion}

European and Japanese larches are two closely related species for which morphological and molecular marker-based discrimination is not a priori obvious. Both species are phylogenetically grouped into the same Eurasian clade (NKONGOLO and KLIMASZEWSKA, 1995; SEMERIKov et al., 2003; WeI and WANG, 2003; GrosLouis et al., 2005) and little interspecific polymorphism has been revealed by molecular markers (VENDRAMIN et al., 1996; SEMERIKov et al., 1999; ACHERÉ et al., 2004). Moreover, both species hybridise easily, both ways, in artificial conditions but also in natural ones when grown close to each other (HENRY and Flood, 1919; Delevoy,
1949). No reproductive barriers seem to exist among them, which is a major criteria to define 'biological' species (MAYR, 1996).

Some morphological features have been described in the literature (DEBAZAC, 1964), which allow to differentiate these two species. But as indicated before, taxonomy of larch species relies mostly on female flower and cone characteristics. So, while discriminant on mature trees, many of these traits cannot be effectively applied on young seedlings. Not only are sexual organs absent but in addition, young seedlings do not yet fully exhibit the typical arrangements of long- and short- (brachyblast) shoots with their respective needle characteristics and 
distribution. Indeed at the end of the first growing season, the seedlings look like long-shoots in more mature trees. They do not produce any short-shoots but some long-shoots (sylleptic branches) can appear in favourable conditions, mostly in the lower part of the stem. During the second growing season, the current stem increment -usually much longer than the first onehas the same long-shoot appearance with usually some sylleptic twigs while some proleptic branches and rare short-shoots may develop on the $1^{\text {st }} \mathrm{yr}$ stem increment. At the end of the second year, both sylleptic and proleptic shoots (a few months old) are of the long-shoot type and do not carry any short-shoots.

Some needle and wood anatomical characteristics found by LAING (1944) proved efficient in discriminating European and Japanese larches and a priori, they could be applied on young plants. Yet, some require a destructive sampling for wood anatomy characterisation and in any case, as they rely on microscopy observation, they could hardly be implemented for routine identification of seedlings.

Taxonomic classification of seedlings is made even more complex here by the consideration not only of pure species but also of their hybrids. Indeed while some hybrids may display typically intermediate traits (e.g. Cupressus macnabiana x sargentii, LitTLE, 2004), hybrids are most usually a mosaic of phenotypes with parental and intermediate characters rather than just intermediate ones as noted by RIESEBERG and ELLSTRAND (1993). This has been observed for many species including forest trees like oaks (KLEINSCHMIT et al., 1995), larches (LAING, 1944), poplars (HINCKLEY et al., 1989) and Nothofagus (StECCONI et al., 2004). This even led RIESEBERG and ELLSTRAND (1993) to conclude that 'from a systematic perspective, the unpredictability of hybrid character expression diminishes the utility of morpho- logical characters for hybrid identification'. This conclusion motivated us to include phenological and growth traits in addition to morphological features.

From both the evaluation and the validation sets of seed orchard progenies, although grown in different climatic conditions, our study showed consistent results with regards to taxa characteristics of young seedlings. Based on results from Tables 4 and 7, they are summarised in Table 9 by comparing hybrid features to those of each pure species encountered in the different hybridisation orchard types and then, more generally to both species.

Considering average seedling characteristics, the hybrids (ELxJL and JLxEL) appeared as intermediate between European and Japanese larches for most traits including some phenological features (LR, BS, NY), stem form (HD), sylleptic branching (SY1, SY2), needles (ULCv, LLCv) and bark (SC) colour. For some other traits, hybrids were closer to either Japanese larch (BF, H1, D1) or to European larch (ULCc) parents and finally, they clearly exceeded the pure species only for growth. Hybrid superiority over pure species for growth has already been reported by several authors (BALTUNIS et al., 2000; LALLY and ThOMPSON, 1998; PÂQUES, 2000) and this characteristic is largely exploited in tree breeding programmes (PÂQUES, 2002).

Because of the intermediacy of hybrids (or similarity with one or the other pure parental species) and also because of the large individual variability found within taxa, no single trait proved efficient in this study for taxa discrimination. This is a frequent result, well-documented in the literature (KREMER et al., 2002; LITTLE, 2004; PonTON et al., 2004). In our study, the combination of 6 to 9 traits proved fairly effective in discriminating species. However, results depended much on orchard seedling lots with misclassifications as low as $2 \%$ or less

Table 9. - Summary of taxa characteristics according to orchard types: Comparison of hybrid larch (HL) to European (EL) and Japanese (JL) larches. The general trend of each trait is given together with the proportion of orchard progenies in which HL significantly differed from parental species.

\begin{tabular}{|c|c|c|c|c|}
\hline \multicolumn{2}{|l|}{ Characteristics } & $\begin{array}{c}\text { in EL } \times \text { JL } \\
\text { orchards } \\
\text { compared to } E L\end{array}$ & $\begin{array}{c}\text { in } \frac{\mathrm{JL}}{\mathrm{x}} \mathrm{EL} \\
\text { orchards } \\
\text { compared to } J L\end{array}$ & $\begin{array}{c}\text { Overall orchards } \\
\text { compared to } E L \& J L\end{array}$ \\
\hline Needles retention in winter & LR & Lower $(8 / 8)$ & Larger (5/6) & Intermediate \\
\hline Bud flushing & $\mathrm{BF}, \mathrm{LBF}, \mathrm{BFD}$ & $\begin{array}{l}\text { Delayed (4/8) or } \\
\text { similar }\end{array}$ & Similar $(2 / 6)$ & $\begin{array}{c}\text { Delayed compared to EL, similar } \\
\text { to JL }\end{array}$ \\
\hline Bud setting & BS & $\begin{array}{l}\text { Delayed }(3 / 8) \text { or } \\
\text { similar }\end{array}$ & Earlier $(3 / 6)$ & Intermediate \\
\hline Fall yellowing of foliage & NY & $\begin{array}{l}\text { Earlier / more } \\
\text { extended (6/8) }\end{array}$ & Similar $(1 / 6)$ & Intermediate \\
\hline \multirow{2}{*}{$\begin{array}{l}\text { Height and diameter } \\
\text { growth }\end{array}$} & H1, D1 & Higher $(6 / 8)$ & Similar $(2 / 6)$ & Higher than EL, similar to JL \\
\hline & $\mathrm{H} 2, \mathrm{D} 2$ & Higher $(7 / 8)$ & Higher (2/6) or similar & $\begin{array}{l}\text { Higher than EL and higher or } \\
\text { similar to JL }\end{array}$ \\
\hline Lamma shoot frequency & LS & $\begin{array}{l}\text { Similar }(0 / 8) \text { but } \\
\text { variable }\end{array}$ & $\begin{array}{l}\text { Similar }(0 / 8) \text { but } \\
\text { variable }\end{array}$ & $\begin{array}{l}\text { Similar (trends towards higher } \\
\text { frequency than both species) }\end{array}$ \\
\hline Stem taper & $\mathrm{HD} 2$ & $\begin{array}{l}\text { Similar but trends to } \\
\text { be slightly lower }(2 / 8)\end{array}$ & Variable $(3 / 6)$ & Intermediate \\
\hline Sylleptic branches number & SY1, SY2 & Larger $(6 / 8)$ & $\begin{array}{c}\text { Similar but trends to be } \\
\text { lower }(1 / 6)\end{array}$ & Intermediate \\
\hline Proleptic branches number & PR1 & Larger $(3 / 5)$ or similar & Similar $(0 / 3))$ & Larger than both species \\
\hline \multirow[t]{2}{*}{ Needles colour } & ULCc, ULCV & Similar $(1 / 5)$ & Lower chroma $(2 / 3)$ & $\begin{array}{c}\text { Lower chroma than JL, similar to } \\
\text { EL, intermediate value }\end{array}$ \\
\hline & LLCc, LLCv & Similar $(2 / 5)$ & Lower value $(2 / 3)$ & $\begin{array}{c}\text { Similar chroma, intermediate } \\
\text { value }\end{array}$ \\
\hline Bark colour & $\mathrm{SC} 1, \mathrm{SC} 2$ & $\begin{array}{l}\text { Darker and more } \\
\text { reddish }(8 / 8)\end{array}$ & $\begin{array}{l}\text { Lighter and less reddish } \\
\qquad(5 / 6)\end{array}$ & Intermediate \\
\hline
\end{tabular}


in some lots (SO1 and SO7) but up to $27 \%$ in the worst situation (SO5). Interestingly, selecting the two most discriminant traits gave similar or even better results and this simplified procedure could prove suitable for routine classification of seedlings.

The main interest is probably to sort out hybrids from pure parental species. Although as a whole, over all orchards, the discriminant functions allow correct classification of $85 \%$ (evaluation set) and $95 \%$ (validation set) of hybrids, hybrids are nevertheless poorly discriminated in some particular orchards. That is clearly the case for the SO2 (crops 1983 and 1987), SO5 and SO6 orchards.

Misclassification of individuals can have several sources. Besides possible errors or biases in trait evaluation (especially for subjective scoring), the insufficient discriminating power of some selected traits could be advocated, particularly in orchard lots with too few seedlings. Another probable explanation is connected to some extrinsic but also intrinsic limitations in the use of the diagnostic molecular markers. Indeed as described by ACHERÉ et al. (2004), the chloroplastic $l l$-Taq1 marker (paternal inheritance) reveals an interspecific polymorphism with specific amplified fragments for European larch and Japanese larch whereas the mitochondrial marker $f-13$ (maternally inherited) amplifies only in Japanese larch. Even with the use of a positive control (pure Japanese larch) as recommended by ACHERÉ et al. and done in this study, the probability that some amplifications of the $f-13$-marker fail is not null. A direct consequence would be the misclassification of some individuals in two situations. The first one is in JLxEL orchard progenies and is easily detectable. Indeed, in case of failure, some $J L x E L$ hybrids will have the same molecular marker pattern as pure European larch (ELxEL). But as the latter is a pedigree not expected in this type of orchard, such errors are thus easily detected and corrected. The second situation is more problematic and concerns progenies from hybridisation orchards where seed is collected on both parental species. From our knowledge, this type of mixed collection is rare in practice but it was exceptionally met in SO2. In case of failure, some JLxEL individuals could be erroneously identified as pure EL (ELxEL) and some pure JL (JLxJL) as $E L x J L$ hybrids. Because all 4 pedigrees are expected in such orchards, errors can hardly be a priori suspected. That is typically the situation with the SO2 lots where the identity of several individuals (at least 4 for SO2.1 and 6 for $\mathrm{SO} 2.2$ ) based on molecular markers is suspected to be erroneous and this most probably explains the lower efficiency of discriminating functions. Obviously, for this type of orchards with mixed progenies, it should be recommended to replicate PCR reactions for confirmation of identities but this was unfortunately not done in this study. Sorting of seedlings from such orchards would also be made easier if seedlots from EL and JL mothers were kept separate so that at least the maternity of the seedlings were known.

Some particular extrinsic causes can also limit the use of the diagnostic molecular markers and can lead to some taxa misclassifications. That is typically when for any reason (e.g. graft rejection, error of selection in arti- ficial local populations), some parental clones are not pure species as expected but themselves already hybrids. In that case, some confusion between backcrossed and one of the parental species progeny is possible. This situation was suspected for SO5 orchard because the DNA analysis of the seedlot showed uncommon banding patterns. A molecular check of SO5 parental clones taxa revealed a posteriori that three of the Japanese larch clones and three of the European larch clones were already in fact hybrids of type JLxEL. As a result, some unknown number of seedlings examined in this study and molecularly identified as pure JL would be in fact backcrosses of type (JLxEL) x JL. A similar situation can also be hypothesised for the SO6 orchard which shares several common clones with SO5.

Unfortunately, the diagnostic cytoplasmic DNA markers used in that study do not allow identifying F2hybrids: nuclear markers still need to be developed.

\section{Conclusion}

Use of phenology, growth, branching and some other morphology traits proved efficient when combined in discriminant functions to differentiate young seedlings of European, Japanese and hybrid larches in mixture. This was validated through several progenies from various types of hybridisation seed orchards and confirmed over two separate experimental periods. From a practical point of view, two traits only (leaf retention during $1^{\text {st }}$ winter and colour of 2 -yr-old seedling bark) proved to be efficient in discriminating taxa, hybrids in particular. Practically, culling of hybrid seedlings could be done in a two-step operation: the first one on 1-year-old seedlings during winter by eliminating pure parental seedlings based on their specific leaf-retention characteristics; the second step during the second winter based on bark colour differences.

Misclassifications occurred mostly in progenies from some problematic orchards creating situations out of range of the normal application of the diagnostic molecular markers used in this study to identify taxa. The search of a more performant mitochondrial marker showing specific bands and of nuclear DNA markers is still needed to solve these particular misclassification problems, particularly with F2-hybrids.

\section{Acknowledgements}

This project was supported by the EU Fair CT98-3354 project 'Towards a European Larch Wood Chain'. We are grateful to our European colleagues and seed orchard managers who provided us the seed orchard lots and to the INRA technical staff for measurements of the trials and for molecular analysis of seedlings. Finally, we are very grateful to two anonymous reviewers who helped us improving the manuscript.

\section{Literature}

ACHERÉ, V. (1999): Recherche de marqueurs moléculaires pour l'identification des mélèzes hybrides (Larix $\mathrm{x}$ eurolepis). Mémoire DEA Univ.Nancy I, 20 pp.

Acheré, V., P. Faivre Rampant, L. E. PÂques and D. Prat (2004): Chloroplast and mitochondrial molecular tests 
identify European-Japanese larch hybrids. Theor. Appl. Genet. 108: 1643-1649.

Baltunis, B. S., M. S. Greenwood and T. Eysteinsson (2000): Hybrid vigor in Larix: growth of intra- and interspecific hybrids of Larix decidua, L. laricina and L. kaempferi after 5-years. Silvae Genet. 47: 288-293.

BergmanN, F. and W. RuETz (1987): Identifizierung von Hybridlärchensaatgut aus Samenplantagen mit Hilfe eines Isoenzym-Markers. Silvae Genet. 36 (2): 102-105.

Braun, H. (1990): Untersuchungen zum Anteil von Hybridlärchen aus einer Samenplantage. Beotr. Forstwirtschaft 24: 151-155.

Debazac, E. F. (1964): Manuel des Conifères. Ed. Ecole Nationale des Eaux et Forêts, Nancy.

Delevoy, G. (1949): Larix eurolepis. Bull. Soc. Centr. Forest. Belgique 56: 178-194.

DesteucQ, O. (2003): Catalogue of Larch basic materials in Europe. 'Towards a European Larch Wood Chain' EU project. Ed. Centre de Recherche de la Nature, des Forêts et du Bois, Gembloux (B).

ENNOS, R. A. and T. QIAN (1994): Monitoring the output of a hybrid larch seed orchard using isozymes markers. Forestry 67: 63-74.

Gros-Louis, M. C., J. Bousquet, L. E. PÂques and N. ISABEL (2005): Species-diagnostic markers in Larix spp. based on RAPDs and nuclear, cpDNA and mtDNA gene sequences, and their phylogenetic implications. Theor. Appl. Genet. Tree Genetics \& Genome 1 (2): 50-63.

HÄCKER, M. and F. BERGMANN (1991): The proportion of hybrids in seed from seed orchard composed of two larch species (L. europaea and L. leptolepis). Ann. Sci. For. 48: 631-640.

Henry, A. and M. G. Flood (1919): The history of the Dunkeld larch. Proc. Royal Irish Acad. Sec. B. 35: p55 in Litterfield \& Eliason.

Hinckley, T. M., R. Ceulemans, J. M. Dunlap, A. Figliola, P. E. Heilman, J. G. Isebrands, G. ScarasciaMugnozza, P. J. Schulte, B. Smit, R. F. Stettler, E. VAN VOLKENBURGH and M. WiARD (1989): Physiological, morphological and anatomical components of hybrid vigor in Populus. In: Structural and functional responses to environmental stresses. Edited by K. H. KREEB, H. Richter and T. M. HincKLEY. SPB Academic Publishing, The Hague, pp. 199-217.

HubERTy, C. J. (1994): Applied discriminant analysis. Wiley-Intesciences (Wiley series in Probability and Statistics), New-York.

Kleinschmit, J. R. G., R. Bacilieri, A. Kremer and A. Roloff (1995): Comparison of morphological traits of pedunculate oak ( $Q$. robur L.) and sessile oak (Q. petraea (Matt.) Liebl.). Silvae Genet. 44: 256-269.

Kremer, A., J. L. Dupouey, J. Cottrell, U. Csaikl, D. Deans, R. Finkeldey, P. Goikoetxea, J. Jensen, A. König, B. Van Dam, A. Ducousso and V. Badeau (2002): Morphological variation in mixed oak stands (Quercus robur and Quercus petraea) is stable across European populations. Ann. For. Sci. 59: 777-787.

LAING, E. V. (1944): Studies on the genus Larix with particular reference to the hybrid larch. Scottish Forestry Journal 58: 6- 32.

Lally, M. and D. Thompson (1998): The advantages of hybrid over European and Japanese larch. Coillte Research and Development, Information note $\mathrm{n}^{\circ} 16$.

LitTle, D. P. (2004): Documentation of hybridization between Californian cypresses: Cupressus macnabiana $\mathrm{x}$ sargentii. Systematic Botany 29: 825-833.
MaYR, E. (1996): What is a Species, and What is Not? Philosophy of Science 63: 262-277.

Munsell color charts for plant tissues, Munsell color New York.

Nkongolo, K. K. and K. Klimaszwska (1995): Cytological and molecular relationships between Larix decidua, $L$. leptolepis and Larix $\mathrm{x}$ eurolepis: identification of species-specific chromosoms and synchronisation of mitotic cells. Theor. Appl. Genet. 90: 827-834.

OstenfELD, C. H. and C. S. LARSEN (1930): The species of the genus Larix and their geographic distribution. Biol. Meddel. Kongel. Danske Vidensk. Selsk. 9: 1-107.

PÂQUES, L. E. (2000): Interspecific hybridisation in larch: the long way to get outstanding varieties. In: Hybrid Breeding and Genetics of Forest Trees. Dungey, H. S., Dieters, M. J. and Nikles, D. G. (Compilers). Proc. of QFRI/CRC-SPF Symposium, 9-14 April 2000, Noosa, Queensland, Australia, pp. 373-385.

PÂQUES, L. E. (2002): Larch tree improvement programme in France. In: Proceedings of the LARIX 2002 symposium, Gap, France, 16-21 Sept.2002; Ed. INRA Orléans, pp. 104-118.

PATSCHKE, W. (1913): Über die extratropischen ostasiatischen Coniferen und ihre Bedeutung für die pflanzengeographische Gliederung Ostasiens. Bot. Jahrb. Syst. 48: $626-776$.

Ponton, S., J. L. Dupouey and E. Dreyer (2004): Leaf morphology as species indicator in seedlings of Quercus robur L. and Q. petraea (Matt.) Liebl.: modulation by irradiance and growth flush. Ann. For. Sci. 61: 73-80.

QIAN, T., R. ENNOS and T. HELGASON (1995): Genetic relationships among larch species based on analysis of restriction fragment variation for chloroplast DNA. Can. J. For. Res. 25: 1197-1202.

RieseberG, L. H. and N. C. Ellstrand (1993): What can molecular and morphological markers tell us about plant hybridization? Critical Reviews in Plant Sciences 12 (4): 213-241.

SAPORTA, G. (1990): Probabilités, analyse des données et statistique. Ed. Technip. Paris.

Scheepers, D., M. C. Eloy and M. BRIQUet (2000): Identification of larch species (Larix decidua, Larix kaempferi and Larix $\mathrm{x}$ eurolepis) and estimation of hybrid fraction in seed lots by RAPD fingerprints. Theor. Appl. Genet. 100 (1): 71-74.

Semerikov, V. L., H. Zhang, M. Sun and M. Lascoux (2003): Conflicting phylogenies of Larix (Pinaceae) based on cytoplasmic and nuclear DNA. Molecular Phylogenetics and Evolution 27: 173-184.

Semerikov, V. L., L. F. SEmerikov and M. LAscoux (1999): Intra- and interspecific allozyme variability in eurasian Larix Mill. species. Heredity 82: 193-204.

Stecconi, M., P. Marchelli, J. Puntieri, P. Picca and L. Gallo (2004): Natural Hybridization between a Deciduous (Nothofagus antarctica, Nothofagaceae) and an Evergreen (N. dombeyi) Forest Tree Species: Evidence from Morphological and Isoenzymatic Traits. Ann. Bot. 94: 775-786.

Vendramin, G. G., L. Lelli, P. Rossi and M. Morgante (1996): A set of primers for the amplification of 20 chloroplast microsatellites in Pinaceae. Molecular Ecology 5: 595-598.

WEI, X. X. and X. Q. WANG (2003): Phylogenetic split of Larix: evidence from paternally inherited cpDNA $\operatorname{trn} \mathrm{T}$ trnF region. Plant Systematics and Evolution 239: 67-77. 